\title{
On Writing Labour Law History: A Reconnaissance
}

Eric M Tucker

Osgoode Hall Law School of York University, etucker@osgoode.yorku.ca

\section{Source Publication:}

International Journal of Comparative Labour Law and Industrial Relations 33(1): 39-58

Follow this and additional works at: https://digitalcommons.osgoode.yorku.ca/scholarly_works

Part of the Labor and Employment Law Commons, and the Legal History Commons

\section{Repository Citation}

Tucker, Eric M, "On Writing Labour Law History: A Reconnaissance" (2017). Articles \& Book Chapters. 2603.

https://digitalcommons.osgoode.yorku.ca/scholarly_works/2603

This Article is brought to you for free and open access by the Faculty Scholarship at Osgoode Digital Commons. It has been accepted for inclusion in Articles \& Book Chapters by an authorized administrator of Osgoode Digital Commons. 


\title{
On Writing Labour Law History: A Reconnaissance
}

\author{
Eric TUCKER *
}

\begin{abstract}
Labour law historians rarely write about the theoretical and methodological foundations of their discipline. In response to this state of affairs, this article adopts a reconnaissance strategy, which eschews any pretense at providing a synthesis or authoritative conclusions, but rather hopes to open up questions and paths of inquiry that may encourage others to also reflect on a neglected area of scholarship. It begins by documenting and reflecting on the implications of the fact that labour law history sits at the margins of many other disciplines, including labour history, legal history, labour law, industrial relations and law and society, but lacks a home of its own. It next presents a short historiography of the writing of labour law history, noting its varied and changing intellectual influences. Next the article notes some of the methodological consequences of different theoretical commitments and discusses briefly the possibilities opened up by computer technologies as revealed by two interesting projects that rely heavily on the construction of sophisticated data bases. Finally, the article reflects on the methodological challenges the author has experienced in his current project on labour law's recurring regulatory dilemmas and conclude with some thoughts on the contribution labour law history can make to our understanding of the dynamics that shape the law's current challenges.
\end{abstract}

\section{INTRODUCTION}

When I was first approached to contribute an article on methodological issues in labour law history, I was both honoured and reluctant to accept the assignment. Why reluctant? To be honest, I had not thought a lot about methodological issues and I suspected not many other labour law historians had published their reflections either. While research was not needed to confirm what I knew about myself, some research was necessary to determine the accuracy of my intuition about other historians' level of reflection.

My methodology was simple. I began by contacting some colleagues and found that none had written on methodological issues. I also did not get many

\footnotetext{
* Professor, Osgoode Hall Law School, York University, Toronto, Canada, Distinguished Scholar in Residence, Cleveland-Marshall College of Law, Cleveland State University, Ohio, USA, email: etucker@yorku.ca. I would like to thank Professors Philip Girard, Doug Hay, Craig Heron, and Michael Quinlan for their helpful suggestions on sources and an anonymous reviewer for her/his comments.
}

Tucker, Eric. 'On Writing Labour Law History: A Reconnaissance'. International Journal of Comparative Labour Law and Industrial Relations 33, no. 1 (2017): 39-58.

(C) 2017 Kluwer Law International BV, The Netherlands 
suggestions about where I might begin. A preliminary literature review found all of three articles, all written over twenty years ago. ${ }^{1}$ In response to the lack of much of a debate or discussion about methodological issues in the writing of labour law history, I have adopted a reconnaissance strategy, ${ }^{2}$ which eschews any pretense at providing a synthesis or authoritative conclusions, but rather hopes to open up questions and paths of inquiry that may encourage others to also reflect on a neglected area of scholarship.

The article begins by documenting and reflecting on the implications of the fact that labour law history sits at the margins of many disciplines, but lacks a home of its own. I then present a short historiography of the writing of labour law history, noting its varied and changing intellectual influences. Next I note some of the methodological consequences of different theoretical commitments and discuss briefly two interesting projects that rely heavily on the construction of sophisticated data bases. Finally, I reflect on the methodological challenges I have experienced in my current project on labour law's recurring regulatory dilemmas and conclude with some thoughts on the contribution labour law history can make to our understanding of the dynamics that shape its current challenges.

\section{WE AIN'T GOT NO HOME}

The successful establishment of a field of study is often marked by the creation of an institutional infrastructure that brings together a group of researchers who share some common understandings about the endeavour in which they are engaged even though they may hold sharply divergent theoretical or methodological commitments. Indeed, the existence of academic societies that hold periodic meetings and sponsor journals provides a setting in which to engage in debates and produce a literature that reflects upon the nature of the enterprise and the commitments and practices of those working in it.

The field of labour history provides a good example of this phenomenon. While labour history was certainly written prior to the 1960s, its emergence

R. L. Hogler, Labor History and Critical Labor Law: An Interdisciplinary Approach to Workers' Control, 30 Lab. Hist. 165 (1989); W. Holt, The New American Labor Law History, 30 Lab. Hist. 275 (1989); C. Tomlins, How Who Rides Whom. Recent 'New' Histories of American Labour Law and What They May Signify, 20 Soc. Hist. 1 (1995).

2 For thoughtful discussion of a reconnaissance strategy, see I. McKay, Reasoning Otherwise 1-4 (Toronto: Between the Lines 2008). Of necessity these reflections are limited to the writing of labour law history in the common law world, weighted heavily towards North America. My selection of work in the citations must also of necessity be quite limited and is somewhat idiosyncratic.

3 My apologies to Woody Guthrie fans. His song 'I Ain't Got No Home in This World Anymore' is about displaced workers in the Great Depression, to which the situation of labour law historians is hardly comparable, but I couldn't resist. 
as an organized field of study was marked by the creation of academic societies (e.g. England (1960), Australia (1961), Canada (1970), and Ireland (1973)), the publication dedicated labour history bulletins and journals (Labor History (US, 1960), Labour History (AU, 1962), Labour/Le Travailleur (now Labour Le Travail) (Canada, 1976) and the holding of labour history conferences. ${ }^{4}$ While it is simplistic to attribute the fortunes of a field to the state of its institutional infrastructure, ${ }^{5}$ there is no doubt both a cause and effect relation between the two. Scholars who identify a common project create an infrastructure that sustains it. The fact that there are no societies, journals or regular conferences dedicated to the field of labour law history may be a function of numbers, but it may also reflect the fact that even among those who write labour law history, many do not identify themselves primarily as labour law historians, but rather as part of some other academic field or sub-field. If nothing else, the absence of any institutional infrastructure has reduced the opportunities for people writing labour law history to engage with each other and to reflect on foundational questions of scope, method and theory, leaving these issues under-examined.

Instead, labour law history lives at the margins and intersections of other fields, most prominently labour history, legal history, labour law, industrial relations and, more recently, law and society. One way of illustrating its marginality, is to consider the number of labour law history papers presented at major conferences in these fields. Here are a number of examples. At the 2015 International Labour and Employment Relations Association (formerly the International Industrial Relations Association) there was not a single paper on labour law history and perhaps one or two that even seemed to promise some kind of historical perspective on its topic. ${ }^{6}$ At the 2015 meeting of the American Society for Legal History, which is not limited to North American legal history, there were about eight papers on various dimensions of slave law and one on labour politics. ${ }^{7}$ At the time of writing, there are even fewer scheduled for its 2016 meeting. ${ }^{8}$ At the 2015 Labour Law Research Network conference, now the leading international conference on labour law research, not a single paper was presented on labour law history and nary a one even seemed to hint at a developed historical perspective on its subject. ${ }^{9}$ And at the 2016 Law and

For a discussion of these developments, see various essays in Histories of Labour: National and International Perspectives (J. Allen, A. Campbell \& J. McIlroy eds., Pontypool, Wales: Merlin Press 2010).

Ibid., at 7.

6 The program is online, http://www.ilera2015.com/index.php/en/the-conference/draft-programme/ file (accessed 3 June 2016).

7 The program is online, http://aslh.net/wordpress/wp-content/uploads/2015/10/2015-ASLHAnnual-Meeting-Program.pdf (accessed 3 June 2016).

8 The program is online, http://aslh.net/wordpress/wp-content/uploads/2016/09/ASLH-Program.pdf (accessed 1 Feb. 2017). 
Society Association meeting, a massive gathering, there were a number of papers and panels on American slavery, and papers on Reconstruction and workers' rights, convict leasing and Mexican peonage. ${ }^{10}$ Labour law historians, or at least labour historians who have a significant interest in law, are probably most likely to present their work at labour history conferences. For example, at the 2015 joint Labor and Working-Class Association and Working-Class Studies Association conference there were a number of papers which, based on their title, suggested they explored some aspect of workers' encounters with state law. ${ }^{11}$ Tellingly, there was no panel explicitly organized as one on labour law history.

A perusal of these programs not only provides evidence that labour law history exists at the margins of these disciplines, at least as they are currently conceived, but it also begins to suggest the difficulties involved in determining the field's domain. For example, while there would be little disagreement that labour law history encompass studies of the law of slavery and other forms of unfree labour, what about immigration laws that crucially affect transnational labour mobility and the threat of deportation for becoming unemployed, or a public charge, or engaging in radicalism? Is the construction of the welfare state, including social security and health care, within the field and does it depend on whether the benefits are delivered through pubic programs or collectively bargained ones? These kinds of questions, of course, are not limited to labour law history. The boundaries of every field and sub-field are permeable and dynamic as people's ideas what constitutes its defining narrative or theoretical foundations change. But I suspect the problem of identification is particular strong in regard to labour law history precisely because of its considerable overlap with other historical sub-fields as well as with other disciplines. So we might also ask whether the people writing on labour law history broadly considered would consider themselves as part of a community of labour law historians with whom they share and would be interested in exploring common historiographic or methodological concerns. Perhaps we need to ask, who the 'we' are who 'ain't got no home', and how that contributes to the limited development of a collective identity which in turn has failed to produce the institutional infrastructure that would support greater reflection on methodological issues in the field.

The program is online, http://get.trudprava.ru/books/trudprava.ru/www/books/LLRN Conference 2015 Amsterdam Program/\#14 (accessed 2 Aug. 2016).

10 The program is online, http://www.lawandsociety.org/NewOrleans2016/docs/2016_Program.pdf (accessed 1 Feb. 2017).

11 The program is online, https://drive.google.com/file/d/0B4-BL7Dqq3a0cUNjQzZDQlVmWGM/ view (accessed 1 Feb. 2017). 


\section{A BRIEF HISTORY OF LABOUR LAW HISTORY}

A good way to begin an exploration of the 'we' and the 'what' of labour law history is by tracing its origins and development. It is notable that labour law history did not emerge out of legal history and was not written by scholars who would have identified themselves as legal historians. This is not surprising given the concerns of early legal historians, such as F.W. Maitland, who although not narrowly doctrinal, was focused on medieval society and its governance. While this would not have ruled out the Tudor law of master and servant, the topic was not in his sights and subsequent scholars, such as S.F.C. Milsom, were even more interested in the 'internal' history of the common law than exploring its relation to the broader polity. As a result, the law regulating workers and work was pushed even further from their view. ${ }^{12}$ Early North American legal historians, a small group at that, also evinced little interest in labour or employment law. This was not surprising given that their work was largely dominated by an internal perspective on common law doctrine. ${ }^{13}$

Rather, early labour law history emerged, along with labour history, in the late-nineteenth and early twentieth centuries among scholars interested in the 'labour question', centred on the role of workers' collective action. In the United States, it was the work of John Commons and his students that dominated the field and gave it a decidedly Progressive tilt that favoured studies of the development of labour institutions, protective labour law such as workers' compensation, and the administrative capacities of the state. Indeed, the so-called Wisconsin school encouraged its members to actively work with government to find solutions to the labour problems of the day. ${ }^{14}$ Although coming from rather different backgrounds, early English labour historians, such as the Webbs, were also concerned with the collective struggles of workers against their employers and a hostile state. ${ }^{15}$ While the picture varied from country to country, ${ }^{16}$ the location

12 M. Lobban, The Varieties of Legal History, 5 Clio@Thémis (2012); J. Rose, Studying the Past: the Nature and Development of Legal History As an Academic Discipline, 31 J. Leg. Hist. 101 (2010).

13 On the US, see G. E. White, The Origins of Modern American Legal History, in Transformations in American Legal History vol. II, 48-63 (D. W. Hamilton \& A. Brophy eds, Cambridge: Harvard University Press 2010); D. Rabban, The Historiography of Late Nineteenth-Century American Legal History, 4 Theoretical Inquiries L. 541 (2003); R. W. Gordon, J. Willard Hurst and the Common Law Tradition in American Legal Historiography, 10 L. \& Socy. Rev. 9 (1975). On Canada, see R. C. B. Risk, A Prospectus for Canadian Legal History, 1 Dalhousie L.J. 227 (1973) and J. McLaren, In the Northern Archives Something Stirred: The Discover of Canadian Legal History, 7 Austrl. J. Leg. Hist. 73 (2003).

14 E. Faue, The United States of America, in Allen, Histories 165-167; B. E. Kaufman, The Origins and Evolution of the Field of Industrial Relations in the United States (Ithaca, NY: ILR Press 1993).

15 J. Allen \& M. Chase, Britain: 1750-1900, in Allen, Histories 65-67; Sidney \& Beatrice Webb, Industrial Democracy (London: Longman's 1897).

16 E.g. G. S. Kealey, Workers and Canadian History 3-31 (Montreal: McGill-Queen's University Press 1995); B. D. Palmer, Canada, in Allen, Histories 196-198; G. Patmore, Australia, in Allen, Histories 231-235. 
labour law history within the field of industrial relations had important implications for its domain and orientation. First, in terms of subject matter, early labour law histories were concerned with legislation and regulatory law and not just the common law which was the focus of most legal historians of the time. Second, industrial relations scholars were not producing 'internal' history, but rather understood that labour law history needed to be understood in relation to wider social forces. Thus, the field was amenable to a law and society orientation from the outset, although when labour lawyers began to write labour law history they tended to be more descriptive and focused on doctrinal development. ${ }^{17}$ Third, the dominant orientation was pluralist and progressive. While the common law was seen to have embodied the conservative prejudices of the judiciary, legislation was characterized as more likely to be responsive to workers' interests and leading to a fairer sharing of the economic pie. ${ }^{18}$

The break of labour and labour law history from an industrial relations frame was both a push and pull phenomenon. On the push side, industrial relations scholarship came to be increasingly dominated by quantitative methodologies designed to better understand the dynamics of collective bargaining within postWorld War II regimes. Historical perspectives that explored the foundations of that regime or prior regimes were of declining interest to scholars in the field. ${ }^{19}$ On the pull side, the rise of social history, often influenced by Marxian views about the structural foundations of class conflict provided a more hospitable intellectual environment for a new generation of historians critical of existing industrial relations and welfare state regimes. The so-called 'new' labour history was concerned with working-class experience more broadly, not just unions and collective bargaining. Studies of working-class communities included social reproduction as well as the problems facing workers at the point of production, giving gender relations and the experience of immigrant and racialized communities a space within the field that was soon filled with excellent studies. ${ }^{20}$ The focus on class

E.g. F. Frankfurter \& N. Greene, The Labor Injunction (New York: Macmillan 1930).

For a discussion of the 'old' labour law history in the US, see Holt, supra n. 1, at 278-281.

For one of many critiques of the industrial relations frame, see C. Tomlins, 'Of the Old Time Entombed': The Resurrection of the American Working Class and the Emerging Critique of American Industrial Relations, 10 Indus. Rel. L. Rev. 426, 428-430 (1988). Also, see A. Campbell \& J. Mcllroy, Britain: The Twentieth Century, in Histories 107 ('Industrial relations developed as a specialized, largely historyfree field fundamentally concerned about policy in the present').

20 Earlier work tended to focus on the skilled, male worker. E.g. in Canada, such studies include B. D. Palmer, A Culture in Conflict: Skilled Workers and Industrial Capitalism in Hamilton, Ontario, 1860-1914 (Montreal: McGill-Queen's University Press 1979) and G. S. Kealey, Toronto Workers Respond to Industrial Capitalism, 1867-1892 (Toronto: University of Toronto Press 1980). Over time, however, the scope of community studies expanded. E.g. see J. Parr, The Gender of Breadwinners (Toronto: University of Toronto Press 1990); B. Bradbury, Working Families: Age, Gender, and Daily Survival in Industrializing Montreal (Toronto: McClelland \& Stewart 1993); C. Heron's recent 
and class formation also pulled the time frame of labour history back to the era before industrial capitalist relations of production had become dominant. ${ }^{21}$

The re-location of labour law history within the field of the new labour history had several significant effects on its development and orientation. First, as labour history's time horizons were extended back in time, the gaze of labour law historians turned to the legal regimes that governed work, before the advent of industrial capitalism including the master and servant regime as well as slavery and other forms of unfree labour. ${ }^{22}$ Indeed, in Britain labour historians 'only occasionally engaged with twentieth-century labour law",23 although that was not the case in North America. ${ }^{24}$ Second, the expanded view of labour history also widened the parameters of labour law history, which now encompassed the legal regulation of workplace health and safety, compensation for work injuries, minimum standards and employment discrimination laws, as well as a revival of interest in the common law. ${ }^{25}$ But with the broader concern about working-class life and a greater appreciation of gender and the close inter-connections between production and social reproduction, the question arises as to how far from the field of paid work should the eye of labour law historians wonder? While no one would quibble with the inclusion of topics such as gendered minimum wage laws, ${ }^{26}$

magisterial study of Hamilton, Lunch-Bucket Lives: Remaking the Workers' City (Toronto: Between the Lines 2015). On the opening of labour history to gender, see J. Sangster, Feminism and the Making of Canadian Working-Class History: Exploring the Past, Present and Future, 46 Lab./Le Travail 127 (2000). On immigration, see F. Iacovetta, Such Hardworking People: Italian Immigrants in Post-War Toronto (Montreal: McGill-Queen's University Press 1992) and D. H. Avery, Reluctant Host: Canada's Response to Immigrant Workers, 1896-1994 (Toronto: McClelland \& Stewart 1995).

21 The influence of E. P. Thompson, The Making of the English Working Class (London: V. Gollancz 1963) and the work of his students (e.g. D. Hay et al., Albion's Fatal Tree (London: Allen 1975)) cannot be underestimated.

22 For a superb collection of studies of the master and servant regime, see Masters, Servants, and Magistrates in Britain \& the Empire, 1562-1955 (D. Hay \& P. Craven eds, Chapel Hill, NC: University of North Carolina Press 2004). For a recent essay that provides an insightful survey of legal histories of unfree labour, slavery and capitalism, see M. A. Axtell, Toward a New Legal History of Capitalism and Unfree Labor: Law Slavery, and Emancipation in the American Marketplace, 40 L. \& Soc. Inquiry 270 (2015). Campbell \& McIlroy Britain, in Allen, Histories, 106-107.

24 E.g. C. Tomlins, The State and the Unions (Cambridge: Cambridge University Press 1985); J. Fudge \& E. Tucker, Labour Before the Law: The Regulation of Workers' Collective Action in Canada, 1900-1948 (Toronto: Oxford University Press 2001).

25 E.g. E. Tucker, Administering Danger in the Workplace: The Law and Politics of Occupational Health and Safety Legislation in Ontario, 1850-1914 (Toronto: University of Toronto Press 1990); P. W. J. Bartrip \& S. B. Burman, The Wounded Soldiers of Industry: Industrial Compensation Policy, 1833-1897 (Oxford: Oxford University Press 1983); D. Roediger \& P. Foner, Our Own Time: A History of American Labor and the Working Day (New York: Verso 1989); A. Kessler-Harris, In Pursuit of Equity (New York: Oxford University Press 2001); C. Mummé, That Indispensable Figment of the Legal Imagination: The Contract of Employment at Common Law in Ontario, 1890 s-1979 (PhD Dissertation, York University 2013) and From Control through Command to the Control of Discretion: Labour Time, Labour Property and the Tools of Managerial Control in Early Twentieth Century Ontraio, 45 Indus. L.J. 176 (2016).

26 E.g. M. E. McCallum, Keeping Women in their Place: The Minimum Wage in Canada, 1910-1925, 17 Lab./Le Travail 29 (1986). 
what about the impact of social welfare and family law on working-class life? ${ }^{27}$ Questions arose in other areas as well. The use of immigration law to deport labour radicals during periods of conflict fits comfortably in labour law history, but what about broader questions of immigration law and policy as a tool to shape the labour supply, often constructed in highly racialized ways? ${ }^{28}$

Then there was the overarching question of the law's autonomy. As long as labour law history remained within a pluralist frame, the question did not arise in a serious way. While pluralists would agree that from time to time the law was out of sync with industrial relations realities, particularly when it was in the hands of the judiciary, they were confident interest group pressures could be counted upon to achieve a functional balance between workers and employers. However, in a Marxian framework the question took on a new importance. Although Marxists were often accused of adopting a simplistic base-superstructure analysis, in which the economic base determined the legal superstructure, labour law historians, particularly those associated with the 'new' labour history, were never so reductionist. For example, although Doug Hay's seminal contribution to Albion's Fatal Tree, 'Property, Authority and the Criminal Law' was not strictly speaking labour law history, his claim that the apparent contradiction between an increasingly bloody criminal law and the relatively small number of lives it claimed could be explained by taking into account the law's dual function of coercion and legitimation. ${ }^{29}$ While this approach left open functionalist interpretations of the law, it complicated any claim that the content of the law could be read off an economic base and left open ample space to explore contradictory forces shaping the law's development and use.

The issue of law's autonomy become more prominent for labour lawyers and legal historians influenced by Critical Legal Studies (CLS) who started writing labour law history in the late 1970s. Initially, many of these scholars came to CLS from a Marxist background and were wedded to a social historical perspective, albeit one that transcended the base-structure metaphor, and located law as constitutive of a social formation with the potential of also being transformative. ${ }^{30}$ For

27 E.g. A. Porter, Gendered States: Women, Unemployment Insurance and the Political Economy of the Welfare State in Canada, 1945-1997 (Toronto: University of Toronto Press 2003) and J. Struthers, No Fault of Their Own: Unemployment and the Canadian Welfare State, 1914-1941 (Toronto: University of Toronto Press 1983). For a call to expand the scope of labour law history to 'all relations in which production occurs and in which productive capacities are renewed' see Tomlins, supra n. 1, at 20.

28 For Canadian examples, see D. Goutor, Guarding the Gates: The Canadian Labour Movement and Immigration, 1872-1934 (Vancouver: University of British Columbia Press 2007;) D. Avery, 'Dangerous Foreigners': European Immigrant Workers and Labour Radicalism in Canada, 1896-1932 (Toronto: McClelland and Stewart 1979).

29 D. Hay, Property, Crime and the Criminal Law in Albion's 17-63.

30 E.g. K. Klare, Law-Making as Praxis, 40 Telos 123 (1979). Also, see his Judicial Deradicalization of the Wagner Act and the Origins of Modern Legal Consciousness, 62 Minn. L. Rev. 265 (1978). 
example, Christopher Tomlins, who was associated with this wave of CLS theorizing, in his first book, The State and the Unions, explicitly embraced neo-Marxist thinking about the state, noting that the relative autonomy of the law was a condition that enabled it to contribute to the reproduction of capitalism. ${ }^{31}$ An implication of this analysis was that law was important because it was a site where class relations are fought over and instantiated, and because the outcomes were not pre-determined and shaped the character of class rule.

However, CLS was soon overtaken by a turn towards radical indeterminacy, which posited that the formative discourse of law was completely autonomous so that no causal connections could be made between law and society. In short, it broke from its prior engagement with Marxian theory, class analysis and materialism, leaving legal history without an explanatory framework to make sense of the path it actually took. ${ }^{32}$ While CLS was more influential in the US than elsewhere, it was part of a larger post-structuralist theoretical turn, which became influential among many labour historians who not only rejected class-based explanations, but who challenged the materiality on which they were based, seeing the world as constructed through discourses unbound from social and economic structures. ${ }^{33}$ Few labour law historians, whether drawn from law schools or history departments, however, followed this turn.

One final framework that influenced the writing of labour law history was the law and society movement. Marked in North America by the founding of the Law and Society Association in 1964, the scholars associated with this movement were united by the idea that law was an object that could be studied and better understood through the social sciences. ${ }^{34}$ The overlaps with CLS and affinities with the social history of law can be traced to a shared rejection of the idea that law and its historical development could be adequately understood from an internal perspective and agreement that law was shaped by external social forces. Not surprisingly, this reproduced the problematic of the law's autonomy as the view of law as a 'selective mirror' was challenged by post-structuralist theory. ${ }^{35}$ Socio-legal scholarship added another problematic, arising out of its embrace of legal pluralism,

Tomlins, supra n. 24.

While D. Kennedy was most responsibility for the radical indeterminacy thesis, its implications for legal history were developed by R. Gordon, Critical Legal Histories, 36 Stan. L. Rev. 57 (1984). For an insightful discussion and devastating critique, see C. Tomlins, What is Left of the Law and Society Paradigm After Critique? Revisiting Gordon's 'Critical Legal Histories', 37 L. \& Soc. Inquiry 155 (2012).

33 For a blistering critique, see B. D. Palmer, Descent into Discourse: The Reification of Language and the Writing of Social History (Philadelphia: Temple University Press 1990).

34 For an accessible intellectual history of the movement by one of its founders, see D. M. Trubek, Back to the Future: The Short, Happy Life of the Law and Society Movement, 19 Fla. St. U. L. Rev. 1 (1990).

35 The language comes from B. Z. Tamanaha, A General Jurisprudence of Law and Society (Oxford: Oxford University Press 2001). For an insightful discussion of the issue of relative autonomy in socio-legal scholarship, see C. Tomlins, How Autonomous is Law?, 3 Annual Rev. L. \& Soc. Sci. 45 (2007). 
an approach which rejects law as a unitary system of command emanating from the state. Rather, legal pluralists take the view that 'the [legal] system has no centre, and is not one system but many. Law emanates from an infinity of sources, permeates all aspects of social and economic life, is as much to be inferred as formally announced, and affects behaviour, positively and negatively through social processes which are as varied as their context'. ${ }^{36}$ For labour law historians, such an approach opens up new avenues of inquiry, such as the historical development of workers' beliefs about the moral economy or norms that should guide their relationships with their co-workers and employers, whether or not those beliefs are recognized in formal state law or not. But are there limits to what we study as law? While few would disagree that studies of the interactions between the Spitafields weavers' beliefs and the web of law and custom in which they were enmeshed fall within the field, what about the history of the rules of the 'game of making out' among mid-twentieth century machine operators? ${ }^{37}$

\section{METHODOLOGICALLY SPEAKING?}

To this point, we have talked more about historiographic and theoretical issues in writing labour law history than we have about methodology. And this is for good reason; methodological choices are to a great extent dictated by historiographic and theoretical commitments. For example, the history of the use of injunctions in the context of strikes and industrial conflict written by Frankfurter and Green from within an industrial relations or industrial pluralist framework draws primarily on reported case law, legislation and secondary literature to examine "whether the labor injunction in action represents a desirable social policy'. ${ }^{38}$ The focus on case law is necessary because the authors are concerned to see whether the outcomes of injunction applications are driven by judicial policy masking as legal principles. For this purpose, a close concern with judicial reasoning and legal process is a crucial methodology. Moreover, Frankfurter and Green's book aimed to promote legislative reforms that in the view of the authors would better instantiate the public policy of promoting greater equality of bargaining power and of making workers' freedom of association more meaningful.

We can contrast this study with an article that Judy Fudge and I wrote more than six decades later on the origins of the labour injunction in Ontario. ${ }^{39}$ Our

\footnotetext{
36 H. Arthurs, Understanding Labour Law: The Debate Over 'Industrial Pluralism', 38 L. \& Soc. Probs. 83, 86 (1985).

37 M. W. Steinberg, 'The Labour of the Country is the Wealth of the Country': Class Identity, Consciousness, and the Role of Discourse in the Making of the English Working Class, 49 Intl. Lab. \& Working-Class Hist. 1 (1996); M. Burawoy, Manufacturing Consent: Changes in the Labor Process Under Monopoly Capitalism (Chicago: University of Chicago Press 1979).

38 Frankfurter \& Green, supra n. 17, at 1.
} 
respective works were separated not only in time, but also by two major theoretical shifts. First, in the field of legal history, there had been a shift from histories of judicial decisions and internal legal processes to social histories of law, which focused on law outside of courts and the complex interactions between law and social forces. The second shift involved a rejection of the pluralist paradigm which envisaged the state and law as playing the role of neutral umpire in favour of a Marxian view of the state as a capitalist state, a site of class conflict, but one driven by the twin imperatives of supporting capitalist accumulation while also maintaining legitimacy. Having been influenced by these shifts, we were concerned with the debate over legal discourse and its role in shaping consciousness and behaviour. We drew a distinction between discourse and ideology, seeing the former as primarily concerned with the internal features of discursive practices and the latter as concerned with their external effects. With regard to law, our concern was with law's external effects, both material and ideological. On the one hand, judicial pronouncements could have severe material effects if they were enforced by the use of coercion, while on the other they may also have ideological effects if they were accepted as normatively just. ${ }^{40}$ These theoretical choices had significant methodological implications. Judicial discourse and legal reasoning was not our primary focus. Rather, we wanted to locate the turn to law by employers against the background of a rich understanding of the conflicts with skilled metal workers in southern Ontario and the tactics these workers used in an effort to protect their bargaining power in the face of employer challenges to their partial control over the labour process. Moreover, we wanted as much as possible to understand the law's ideological effect as well as its coercive role. Given these goals, we relied heavily on non-legal primary sources such as newspapers and archival records, as well as the writing of new labour historians who shared our general perspective and concerns.

However, methodological considerations are not entirely driven by historiographic and theoretical commitments. They may also be influenced by the researcher's resources and technical capabilities, particularly when it comes to the use of computers and technology. Two illustrative examples will suffice. The first comes from Australia where Michael Quinlan and his associates have painstakingly assembled a database on Australian trade unions between 1825 and 1925 in order to provide a more complete picture of workers' collective activity than had been available from earlier surveys and single-union studies. Within that data base are five sub files, two of which are directly related to labour law history. The first

\footnotetext{
39 E. Tucker \& J. Fudge, Forging Responsible Unions: Metal Workers and the Rise of Labour Injunction in Canada, 37 Lab./Le Travail 81 (1996).

$40 \quad$ Ibid., at 82-86.
} 
is the deputation and petition sub file that includes records of unions or groups of workers seeking government action, whether in the form of legislation or change of policy. The second sub file relates to court actions involving unions or their members arising out of industrial conflict. A preliminary analysis of legal interventions found that courts played a greater role in labour conflict than was thought by previous labour historians and that particular groups of workers (rural labourers, seamen and miners) were significantly more likely to face legal action by their employers than others. As well, the analysis suggested two patterns of legal activity, one based on the prosecution of workers under master and servant laws imposing discipline on a footloose workforce, and the other based on common law to limit picketing and other strike support actions by skilled workers during periods of conflict. A later study of Australian seamen found that health and safety issues were the leading cause of workplace protest and provided interesting insights into the largely unsuccessful efforts of seamen to use the law to pursue claims that ships were unseaworthy and that their onboard treatment was unlawful. ${ }^{41}$

While such databases have enormous potential to provide a better understanding of the role of labour law on the ground, the difficulties of creating them should not be underestimated. First, once researchers move beyond reported case law, assembling anything like a comprehensive set of workers' legal engagements is challenging. In the Australian case, Quinlan et al. relied primarily on newspaper reports, which were supplemented by searches of a variety of other relevant record groups, such as magisterial benchbooks, when they were located. This was a painstaking and time-consuming task, which started in 1982 and, even using a numerous research assistants, had not been completed by 1994. Not only did it require massive searches, but computer expertise was required to customize the software and update it as newer applications replaced older ones that become obsolete. Needless to say, all this requires a deep commitment on the part of researchers and is resource intensive. ${ }^{42}$

A second example is drawn from Douglas Hay and Paul Craven's magisterial (in two senses of the word) master and servant project, which had several

41 M. Quinlan \& M. Gardner, Researching Industrial Relations History: The Development of a Database on Australian Trade Unions 1825-1900, 66 Lab. Hist. 90 (1994) and Strikes, Worker Protest, and Union Growth in Canada and Australia, 1815-1900: A Comparative Analysis, 36 Lab./Le Travail 175 (1995). M. Quinlan, The Low Rumble of Informal Dissent: Shipboard Protests over Health and Safety in Australian Waters, 1790-1900 102, Lab. Hist. 1 (2012).

42 For our book Labour Before the Law, Judy Fudge and I constructed a database of 'strikes with legals' that drew primarily from reports of strikes in the government publication, Labour Gazette. We soon discovered that the reporting was less than comprehensive and added new entries as we and our research assistant found them. However, we lacked the resources and commitment necessary to create a more comprehensive database, let alone to maintain it once the book was completed. 
components. First, they assembled an outstanding group of scholars to contribute studies of master and servant law in action over a dozen jurisdictions in the British Empire that each required detailed research to identify the statutes in force and more importantly their use, a task complicated by the fact that enforcement occurred at the level of the magistracy and so did not produce a significant body of reported case law. ${ }^{43}$ A second dimension of the project was to analyse the diffusion of master and servant statutes across the Empire. This turned out to be an even more daunting task than Hay and Craven initially anticipated, involving more than 2000 statutes and ordinances in over 200 colonies. ${ }^{44}$ To manage and analyse such a mass of legislation, the authors created a data base that contained an inventory of statutes, a codebase, which allowed for comparisons between statutes, and a textbase, which contained the full text of all principal statutes. The authors developed sophisticated strategies to identify patterns in the dissemination of statutory language between jurisdictions, whose description is beyond the scope of this survey (or my understanding), finding about 500 'parent' statutes, 26 of which were prolific as measured by the number of offspring they generated. Whatever one may make of the results of this part of the study, researchers must have, acquire or hire someone on the team with highly sophisticated and specialized computing skills to use this and similar methodologies.

\section{THEORETICAL AND METHODOLOGICAL CHALLENGES IN WRITING LABOUR LAW'S RECURRING REGULATORY DILEMMAS}

The idea for labour law's recurring regulatory dilemmas arose in the aftermath of the publication of Labour Before the Law. In the course of the manuscript review process, one of the readers suggested that there were really two books lurking in the manuscript, one a focused study of the collective bargaining regime from 1900 to the adoption of the Wagner-Act model of collective bargaining in Canada during and at the end of World War II, and the other a broader study of the history of labour law from the beginnings of Canada to the present. Since the first book could be extracted from the existing manuscript, while the second would require several more years of work, Judy Fudge and I took the prudent course of publishing the more focused study.

\footnotetext{
43 This work is collected in D. Hay \& P. Craven, Masters, Servants, and Magistrates in Britain and the Empire, 1562-1955 (Chapel Hill, NC: University of North Carolina Press 2004).

44 D. Hay \& P. Craven, Introduction in Masters 10-21. For earlier reports on the project, see their Master and Servant in England and the Empire: A Comparative Study, 31 Lab./Le Travail 175 (1993) and Computer Applications in Comparative History: The Master and Servant Project at York University (Canada), 7 Hist. \& Computing 69 (1995).
} 
But the reviewer had planted the seed of another book in our heads, a comprehensive history of labour and employment law in Canada. The task, however, was daunting, especially since we did not want to take a law from above approach that would be based on superior court judgments and legislation. I drafted a couple of chapters on the nineteenth century before we gave up on the project, in part because our interests were shifting in other directions, but also because our commitment to a social historical project imposed immense methodological challenges in terms of assembling and analysing the sources that would be necessary to successfully complete the project.

A few years later while looking through one of those draft chapters a case caught my eye whose significance had eluded me earlier. The case, Welch $v$. Ellis, was an 1895 judgment of the Ontario Court of Appeal which addressed a claim by Welch that pursuant to Ontario's corporation statute the directors were personally responsible for the unpaid wages owed to him. ${ }^{45}$ Welch was unsuccessful because the court narrowly interpreted the scope of the protected class of wage earners, but what I found startling was the fact that a nineteenth-century incorporation act imposed director liability for unpaid wages owed by the corporation. I knew that current Canadian law imposed limited director liability for unpaid wages, but I had always assumed that this was a modern development, not an artefact of nineteenthcentury law.

This revelation led me on a quest to find the roots of director (and as I discovered, its predecessor, shareholder) liability for unpaid wages owed by the corporation, which I found in early nineteenth-century debates in America over the enactment of general incorporation statutes that would allow investors to create for-profit businesses that could operate while avoiding personal liability for its debts beyond the amount of their investment. ${ }^{46}$ The principle of limited liability was inconsistent with the prevailing norm of personal responsibility and the burden of justifying this exception treatment of investors fell on those advocating it. They faced strong opposition from a variety of groups, including producer republicans who were united in defence of independent artisan and commodity production against the growth capitalist enterprises and wage labour. The struggle against general incorporation statutes was lost but a concession was made to protect wage earners against the risk of corporate default on the payment of wages. Legislators recognized that workers and their families were dependent on their wages, which made this debt different than the corporation's other contractual obligations. As a result, early general incorporation statutes provided that shareholders remained personally liable for unpaid wages by the corporation. The

Welch v. Ellis (1895), 22 O.A.R. 255.

46 The following discussion summarizes my Shareholder and Director Liability for Unpaid Workers' Wages in Canada: From Condition of Granting Limited Liability to Exceptional Remedy, 26 L. \& Hist. Rev. 57 (2008). 
retention of this obligation was necessary to legitimate the granting investors an exception from the then prevailing norm of personal responsibility for business losses. In the latter part of the nineteenth century, for reasons I could not locate in the historical record, Canada substituted director liability for shareholder liability. By the time Welch v. Ellis was decided at the turn of the twentieth century, however, the ideological ground had shifted and the norms of capitalist legality, which include limited liability for corporations, had become the hegemonic common sense of the law, so that statutory provisions that made directors personally responsible for unpaid wages by the corporation were exceptional and to be narrowly construed. The article then traced the judiciary's role in narrowing the scope of protective labour law through a series of cases culminating in the Supreme Court of Canada's judgment in a late-twentieth century case, Barrette v. Crabtree. ${ }^{47}$

Writing the article posed numerous theoretical and methodological challenges. At a basic level, the story could have been (and to an extent was) written as doctrinal history, tracing how superior court judges interpreted and applied the law over time. At that level, traditional legal research methods of case analysis were sufficient. However, the ambition of the article, and of the project more generally, is greater. At a theoretical level, I start from the premise that in any economic regime that is based on the ability of one class to both dominate and exploit the labour of others ${ }^{48}$ labour law is going to play at least two roles: a facilitative or disciplinary one that will assist those extracting the benefit and a protective role that will place some limits on the means used and/or the extent of the extraction. While this proposition might be supported on the basis of a Polanyian-type functionalist argument (societies in general, and market societies in particular, will self-destruct if social limits are not placed on labour extraction/commodification), I hypothesized that the presence of these two functions is better explained from within a class-conflict framework, where both those who extract labour and those whose labour is extracted are actively engaged in protecting their interests. From within this framework, it is easy to explain the disciplinary dimensions of labour law, but more difficult to account for its protective dimensions since historically subordinated workers are less able to have the state act as their agent. While such an approach lends itself to a reductionist account of law in which law simply reflects the existing balance of power in class relations, I endeavour to avoid that result by also recognizing that for a variety of reasons that themselves will shift over time, law as a system of rule must appear and to an extent operate independently from the sphere of economic relations and the interests of particular classes.

[1993] 1 SCR 1027.

48 Here I draw on the work of Erik Olin Wright, Understanding Class (New York: Verso 2015), where he distinguishes between domination and exploitation, defining the latter as the ability to extract a benefit from another's labour. 
These reasons include the normative foundations of the rule of law within a social formation, including the rules that govern discourse formation, which vary over time but are not usually reducible to the logic of the economic formation. This is the foundation of law's relative autonomy. But because conflict is embedded in social and economic structure, my argument is that labour law will be beset by recurring regulatory dilemmas that can never be finally resolved but rather will be managed differently over time in response to shifting interests as they are mediated through politics and law. ${ }^{49}$

Regardless of whether one accepts the theoretical premises of the project, the important point here is that it poses serious methodological challenges. First, there is the question of the time frame of the analysis. Since my argument is that regulatory dilemmas are recurring, while a focused case study of a particular event may reveal the presence of a regulatory dilemma at a moment in time, it fails to address the larger question of whether those dilemmas are recurring over time. Thus while I greatly appreciate the contribution such studies can make and have written several myself and co-edited collections of them, ${ }^{50}$ I could not possibly use this method here. My challenge then was to get beyond traditional case law analysis without being able to achieve the depth and richness that one gets from detailed case studies. It would have been ideal if I discovered a rich secondary literature that I could have drawn upon to weave a larger interpretive narrative, but the topic has, with some exceptions, attracted limited attention. The exceptions were largely limited to American studies of resistance to general incorporation statutes and limited liability in the early nineteenth century. This turned out to be quite helpful since the first general incorporation statute in Canada was inspired by the New York law, where resistance to such a law had been especially strong. However, the history of shareholder/director liability for unpaid workers' wages after the adoption of the first general incorporation statutes in Canada was practically a blank slate. As a result, I had to make strategic choices about where to dig more deeply and in some cases the historical record simply did not seem to yield answers, as was the case for understanding the switch from shareholder to director liability that occurred in the 1860s. Similarly, when I turned to the history of wage priority in bankruptcy I found practically nothing had been written on the topic despite the fact that there has been a recent surge of interest in the history of bankruptcy and business failure, particularly in England and the United States. ${ }^{51}$

49 For my initial attempt to develop the theme of labour law's recurring regulatory dilemmas, see Renorming Labour Law: Can We Escape Labour Law's Recurring Dilemmas?, 39 Indus. L.J. 99 (2010). For an insightful discussion of the relative autonomy debate, see Tomlins, supra n. 35 .

50 E.g. J. Fudge \& E. Tucker, Work on Trial: Canadian Labour Law Struggles (Toronto: Irwin Law and the Osgoode Society for Canadian Legal History 2010); E. Tucker, Hersees of Woodstock Ltd. v. Goldstein: A Small Town Case Made it Big, in Fudge \& Tucker, Work 217-248. 
The focus of those studies, however, is on other issues such as whether and when bankrupts should be released from their debts. The lack of attention paid to wage priority by historians was not just a function of their interests, but seems also to accord with the weight of the historical record. While limited wage priority was normally found in early modern and modern bankruptcy statutes, there was little public debate over the matter and they were not controversial when legislation was enacted. Thus the sparsity of evidence in the historical record posed both a methodological challenge and a theoretical one given my starting premises.

A second methodological and theoretical challenge derived from the long view being taken was that some regulatory dilemmas had roots in the agrarian and mercantile economy that pre-dated capitalism. This was not so much the case with shareholder/director liability because of relatively late advent of general incorporation statutes, but it was the case for other areas where regulatory dilemmas arose, such as for wage priority in bankruptcy, where the norm of paying one's servants first was entrenched in early modern England, well before the rise of industrial capitalism. As a result, I could not confine my study to regulatory dilemmas within capitalism (which itself is not static) but had consider how those dilemmas arose and were managed in regimes where pre-capitalist economic and pre-liberal political and legal relations predominated, and then to examine how the resolution of those dilemmas in early modern England provided the foundation from which regulatory dilemmas recurred and were managed in an emerging and developing capitalist social formation. At a theoretical level it required recognition that the "law's developmental autonomy varies across different periods ${ }^{52}$ and that it is also likely to vary across different aspects of labour and employment law, some of which are more contentious than others.

A final methodological challenge arose in regard to studying the law in action. While it was possible to trace laws imposing shareholder/director liability for unpaid workers' wages or giving workers' wages limited priority in bankruptcy and to uncover legislative debates, such as they were, it was much more difficult to uncover evidence about the extent and circumstances in which these laws were invoked. The reported case law is thin and presumably only represents a small

51 S. A. Sandage, Born Losers: A History of Failure in America (Cambridge, MA: Harvard University Press 2005); B. H. Mann, Republic of Debtors: Bankruptcy in the Age of American Independence (Cambridge: Harvard University Press 2002); E. J. Balleisen, Navigating Failure: Bankruptcy and Commercial Society in Antebellum America (Chapel Hill, N.C.: University of North Carolina Press 2001); D. Skeel, Debt's Dominion: A History of Bankruptcy Law in America (Princeton: Princeton University Press 2001). Since beginning my research, Thomas Telfer published a legal (but not a socio-legal) history of Canadian bankruptcy law. See his Ruin and Redemption: A Struggle for Canadian Bankruptcy Law, 1867-1919 (Toronto: University of Toronto Press, Osgoode Society for Canadian Legal History 2014).

52 H. Schweber, Lochner v. New York and the Challenge of Legal Historiography, 39 L. \& Soc. Inquiry 242 at 246 (2014). 
sample of cases in which legal claims were made since most cases are resolved through negotiation and, at least until recently, only a limited number of judgments were published. It is also the case that in Canada at least social historians have not delved deeply into the history of business failure and so it is difficult to provide the broader context within which these laws operated, although the situation improves for the last decades of the twentieth century. These problems, however, are not endemic to all of the recurring regulatory dilemmas I am investigating. Not only have workers' compensation and occupational health and safety regulation received more attention from historians, but the ongoing struggles over the implementation of these schemes and persistent attempts to reconstruct them have from time to time become significant goals for the labour movement and employer organizations, producing a rich and accessible historical record.

\section{CONCLUDING THOUGHTS}

Outside of the United States, labour law historians comprise a small group. ${ }^{53}$ In countries like Canada and Australia there are at most a handful of scholars who at any one time might identify themselves as labour law historians and typically they are active researchers, and perhaps better known, in other areas, such as occupational health and safety regulation, where the demand for (and funding to support) legal and policy research is far greater than for labour law history. ${ }^{54}$

Moreover, labour law history lies at the intersection of a number of better established disciplines, including labour law, labour history and legal history, and has never really emerged as an institutionalized sub-discipline of any one these, let alone as a discipline in its own right. This situation has contributed to the relative paucity of self-reflection on theoretical and methodological issues in writing labour law history.

The under-developed institutionalization of the field, however, should not be taken as an indication of its lack of relevance or intellectual challenge. Occasionally, labour law history becomes important for litigation. In Canada, for example, the history of the right to bargain collectively and to strike was considered by the Supreme Court in reaching the conclusion that these rights were constitutionally protected under the right to freedom of association. ${ }^{55}$

53 The case of the United States is arguably an exception in numbers. The scholarly production of American labour law history outstrips that of any jurisdiction with which I am familiar. However, it is not clear how many of these authors self-identify as labour law historians. For a small sample of recent excellent books, see N. Woloch, A Class By Herself: Protective Laws for Women Workers, 1890-1990s (Princeton: Princeton University Press 2015); S. Z. Lee, The Workplace Constitution: From the New Deal to the New Right (New York: Cambridge University Press 2014); J.-C. Vinel, The Employee: A Political History (Philadelphia: University of Pennsylvania Press 2013).

54 E.g. Michael Quinlan and I share these interests. 
However, the production of history for the purposes of litigation has a bad reputation as 'law office history' and may have a distorting influence on methodological and interpretive judgments. ${ }^{56}$ Instead, by relevance I refer to the ability of history to illuminate current concerns, not through a whiggish celebration of the progress of the law or, more likely in these times, a story of rise and decline, but rather through developing a deeper understanding of the forces that have shaped and continue to shape labour laws and institutions. ${ }^{57}$ I appreciate this is not a universally shared perspective among labour law historians, some of whom would eschew such claims and insist that the past is the past and the most we can do is to situate labour law history in its particular context as best we can. ${ }^{58}$ In either version, labour law history presents intellectual and methodological challenges, which continue to evolve as new perspectives on law, labour and history emerge.

55 Health Services and Support - Facilities Subsector Bargaining Assn. v. British Columbia, 2007 SCC 27, paras 40-68; Saskatchewan Federation of Labour v. Saskatchewan, 2015 SCC 4. For my views on the use of history in the first case, see The Constitutional Right to Bargain Collectively: The Ironies of History in the Supreme Court of Canada, 61 Lab./Le Travail 60 (2008).

56 The phrase was coined by A. H. Kelly, Clio and the Court: An Illicit Love Affair Supreme Court Review 119 (1965). For an interesting and perhaps ironic defence, see M. Tushnet, Interdisciplinary Legal Scholarship: The Case of History-in-Law, 71 Chi.-Kent L. Rev. 909 (1996). In Health Services, the Supreme Court of Canada cited historical work I had authored or co-authored well before there was any prospect of it being considered in constitutional litigation. Subsequent to that litigation, Judy Fudge and I wrote on the legal history of the freedom to strike. The work was not written for litigation purposes but we were both aware that this article would be relevant in expected litigation claiming a constitutional right to strike. That knowledge kept mindful of the need to be certain our work would withstand critical scrutiny if other historians were called upon to challenge our conclusions. In the event, we were not asked to provide expert witness affidavits for the Saskatchewan Federation of Labour litigation, but our article was relied upon by the majority judgment in the support of its conclusion that the freedom to strike is constitutionally protected. J. Fudge \& E. Tucker, The Right to Strike in Canada: A Brief Legal History, 15 Can. Lab. \& Empl. L.J. 333 (2009-2010); Saskatchewan Federation of Labour, paras 37-38, 44, 54-55.

57 This is the premise of the recurring regulatory dilemmas project described above.

58 E.g. see J. Webber, Labour and the Law, in Labouring Lives 105-203 (P. Craven ed., Toronto: University of Toronto Press 1995) for an outstanding overview and periodization of nineteenth-century Ontario labour and employment law that makes no large assertions about the forces shaping the law's development, but rather sees the law adjusting incrementally in response to a combination of external demands and internal imperatives. 